\title{
Oleanolic acid, a pentacyclic triterpene attenuates capsaicin-induced nociception in mice: Possible mechanisms
}

\author{
Juliana L. Maia ${ }^{a}$, Roberto C.P. Lima-Júnior ${ }^{a}$, Caroline M. Melo ${ }^{a}$, Juceni P. David ${ }^{b}$, \\ Jorge M. David ${ }^{\mathrm{c}}$, Adriana R. Campos ${ }^{\mathrm{a}}$, Flávia A. Santos ${ }^{\mathrm{a}}$, Vietla S.N. Rao ${ }^{\mathrm{a}, *}$ \\ ${ }^{a}$ Department of Physiology and Pharmacology, Faculty of Medicine, Federal University of Ceara, POB-3157, 60430-270 Fortaleza, CE, Brazil \\ ${ }^{\mathrm{b}}$ Pharmacy Faculty, Federal University of Bahia, 1401-70-250 Salvador, Brazil \\ ${ }^{\mathrm{c}}$ Institute of Chemistry, Federal University of Bahia, 1401-70-250 Salvador, Brazil
}

Accepted 13 June 2006

\begin{abstract}
The anti-inflammatory pentacyclic triterpene, oleanolic acid (OA) was examined on acute nociception induced by intraplantar injection of capsaicin in mice. OA administered orally to mice at 10,30 and $100 \mathrm{mg} \mathrm{kg}^{-1}$, significantly attenuated the paw-licking response to capsaicin $(1.6 \mu \mathrm{g} / \mathrm{paw})$ by $53 \%, 68.5 \%$ and $36.6 \%$, respectively. Ruthenium red $\left(3 \mathrm{mg} \mathrm{kg}^{-1}\right.$, s.c.), a non-competitive vanilloid receptor (V1, TRPV1)antagonist also suppressed the capsaicin nociception by $38.6 \%$. The maximal antinociception produced by $30 \mathrm{mg} \mathrm{kg}^{-1} \mathrm{OA}$ was significantly blocked in animals pre-treated with naloxone $\left(2 \mathrm{mg} \mathrm{kg}^{-1}\right.$, i.p.), the opioid antagonist; L-arginine $\left(600 \mathrm{mg} \mathrm{kg}^{-1}\right.$, i.p.), the substrate for nitric oxide synthase; or glibenclamide $\left(2 \mathrm{mg} \mathrm{kg}^{-1}\right.$, i.p.), the $\mathrm{K}_{\mathrm{ATP}}$-channel blocker, but was unaffected by yohimbine $\left(2 \mathrm{mg} \mathrm{kg}^{-1}\right.$, i.p.), an $\alpha_{2}$-adrenoceptor antagonist. In open-field and rota-rod tests that detect motor deficits, mice received $30 \mathrm{mg} \mathrm{kg}^{-1} \mathrm{OA}$ did not manifest any effect per se, indicating that the observed antinociception is not a consequence of motor abnormality. These data suggest that OA inhibits capsaicin-evoked acute nociception due to mechanisms possibly involving endogenous opioids, nitric oxide, and $\mathrm{K}_{\mathrm{ATP}}$-channel opening.
\end{abstract}

(C) 2006 Elsevier Ltd. All rights reserved.

Keywords: Oleanolic acid; Pentacyclic triterpene; Capsaicin; Antinociceptive activity; Endogenous opioids; Nitric oxide; $\mathrm{K}_{\mathrm{ATP}}$-channels

\section{Introduction}

The capsaicin receptor TRPV1 (transient receptor potential vanilloid 1) is a $\mathrm{Ca}^{2+}$ permeable non-specific cation channel that mediates chemical and thermal pain. TRPV1 receptors are expressed primarily in small sensory neurons type $\mathrm{C}$ and A $\delta$ fibers and to a less extent in other tissues and initiate a complex cascade of events, including neuronal excitation and release of pro-inflammatory mediators, desensitization of receptor, and neuronal toxicity [1-3]. These receptors are activated by vanilloids (capsaicin, resiniferatoxin, piperine, etc.) and nonvanilloid endogenous ligands (protons, anandamide, bradykinin and lipoxygenase products) as well $[4,5]$. The functional role of TRPV1 in acute and chronic nociception has been established by the use of TRPV1 antagonists, and TRPV1 knockout mice $[6,2,7]$. Currently, TRPV1 agonists and antagonists are

\footnotetext{
* Corresponding author. Tel.: +55 853366 8341; fax: +55 8533668333 .

E-mail address: vietrao@ufc.br (V.S.N. Rao).
}

both being developed for the treatment of pain. The desensitization induced after TRPV1 agonists points to the utility of these agents in the suppression of neuropathic pain, whereas, TRPV1 antagonists as valuable agents for the treatment of inflammatory, postoperative and arthritic pain [8,9]. Some of these antagonists like ruthenium red and capsazepine may further serve as molecular tools in drug investigations. However, the available compounds show only moderate potency, limited selectivity, poor pharmacokinetics and species differences [7]. Therefore, the search for more potent and ideal TRPV1 antagonists effective for the treatment of painful neuropathy continues.

A number of natural sources have been examined for the development of drugs acting as agonists or antagonists at vanilloid receptors, which include compounds like polygodial, a full vanilloid agonist derived from marsh pepper; warburganal from the bark of warburgia trees; isovelleral with terpenoid structure isolated from fungi; scalaradial, an unsaturated dialdehyde isolated from sponges; and scutigeral, isolated from edible mushrooms [10]. Oleanolic acid (OA) is a pentacyclic triterpene 


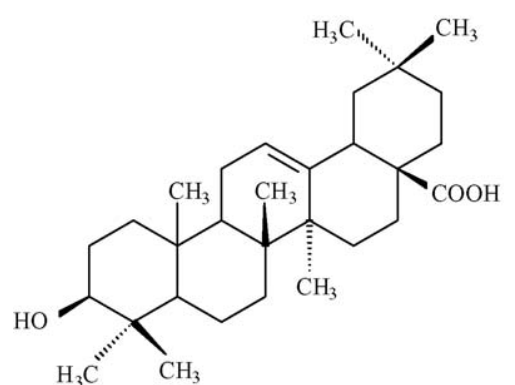

Fig. 1. Chemical structure of oleanolic acid.

that pertains to oleanane series (Fig. 1) naturally found in various medicinal herbs traditionally used for anti-inflammatory, analgesic, hepatoprotective and cardiotonic effects [11]. Plant extracts rich in OA have been shown to exhibit antinociceptive property in hotplate, tail-flick and writhing models of nociception [12] and a beneficial effect on pain in arthritic subjects [13]. Previous investigations on $\mathrm{OA}$ established the gastroprotective, hepato-protective, anticancer and anti-inflammatory effects [14-16]. In a recent study, we have shown that the oleanolic acid suppresses visceral nociceptive pain induced by intracolonic mustard oil in mice in a naloxone-sensitive manner [17] and the present experiments were designed to extend these studies to verify a possible suppressive effect of OA on capsaicin-induced acute hind paw nociception and the possible mechanisms, in mice.

\section{Materials and methods}

\subsection{Animals}

Male albino Swiss mice (20-25 g) obtained from the Central Animal House of the Federal University of Ceara were utilized. They were maintained in polypropylene cages at a room temperature of $23 \pm 2{ }^{\circ} \mathrm{C}$ and humidity of $55 \pm 10 \%$ on a regulated $12 \mathrm{~h}$ light/dark cycle. They had free access to standard laboratory chow (Purina, Brazil) and drinking water. When the compound was given orally, the mice were fasted overnight with free access to drinking water. Mice were habituated to the ambient at least $2 \mathrm{~h}$ before the behavioral testing. All experiments were performed in accordance with the ethical guidelines of the International Association for the study of pain [18] and were approved by the Federal University of Ceará Ethics Committee on Animal Research. All efforts were made to minimize the number of animals used and their suffering.

\subsection{Plant material and isolation of oleanolic acid}

The aerial parts ( $2.4 \mathrm{~kg}$ ) of Eriope blanchetii (Benth.) Harley (Lamiaceae) was collected from the Metropoliton Park area of Abaeté (Salvador, BA) after its identification and the voucher specimen (no. 045599) was retained in Alexandre Leal Costa Herbarium, Institute of Biology, Federal University of Bahia. Oleanolic acid was extracted and isolated from the dried plant material as per procedures described earlier [19]. For experiments, oleanolic acid was suspended in aqueous Tween 80 solution (2\%) and control groups were treated with this vehicle in a similar volume as for test groups.

\subsection{Chemicals and drugs}

The following chemicals and drugs were used: capsaicin (8methyl- $N$-vanillyl-6-nonamide, Calbiochem, San Diego, CA, USA); naloxone (Dupont, Garden City, USA); morphine hydrochloride (Cristalia, São Paulo, Brazil); L-arginine, diazoxide. glibenclamide, clonidine, yohimbine, and ruthenium red (Sigma Chemical Co., St. Louis, MO, USA). All other chemicals used were of analytical grade. Capsaicin was dissolved in a vehicle comprising of ethanol, Tween 80 and normal saline $(1: 1: 8)$. All other drugs were dissolved in normal saline.

\subsection{Capsaicin-induced acute hind paw nociception in mice}

Capsaicin $(1.6 \mu \mathrm{g}$ in $20 \mu \mathrm{l})$ or vehicle was injected intraplantar using a microsyringe with 26-gauze needle, and personnel unaware of the treatments recorded visually the amount of time the animals spent licking the injected paw for a period of $5 \mathrm{~min}$ [20]. Each animal was used only once for experimentation. The test doses of OA $\left(10,30\right.$, and $100 \mathrm{mg} \mathrm{kg}^{-1}$, p.o.), ruthenium red ( $3 \mathrm{mg} \mathrm{kg}^{-1}$, s.c.) or the vehicle used for dissolving OA $\left(10 \mathrm{mg} \mathrm{kg}^{-1}\right.$, p.o.) were administered $60 \mathrm{~min}$ before capsaicin. To verify the possible participation of endogenous opioids, $\alpha_{2}$ adrenoceptors, nitric oxide (NO) or $\mathrm{K}_{\mathrm{ATP}}$-channel-opening in the antinociceptive effect of $\mathrm{OA}$, naloxone $\left(2 \mathrm{mg} \mathrm{kg}^{-1}\right.$, i.p.), L-NAME (20 $\mathrm{mg} \mathrm{kg}^{-1}$, i.p.), yohimbine $\left(2 \mathrm{mg} \mathrm{kg}^{-1}\right.$, i.p. $)$, or glibenclamide $\left(2 \mathrm{mg} \mathrm{kg}^{-1}\right.$, i.p.) pre-treated groups of animals were included, in which case the antagonists were administered $15 \mathrm{~min}$ before the OA. Morphine $\left(5 \mathrm{mg} \mathrm{kg}^{-1}\right.$, s.c.), clonidine (0.1 $\mathrm{mg} \mathrm{kg}^{-1}$, i.p.), L-arginine $\left(600 \mathrm{mg} \mathrm{kg}^{-1}\right.$, i.p.), diazoxide $\left(2 \mathrm{mg} \mathrm{kg}^{-1}\right.$, i.p.)-alone or their combinations treated groups were also included. Sixty minutes after oleanolic acid or $30 \mathrm{~min}$ following morphine, clonidine or L-arginine administrations, capsaicin test was carried out as described earlier. Saline treated controls (normal) that did not receive capsaicin and vehicletreated controls that received capsaicin were also included. The dose selections for capsaicin $(1.6 \mu \mathrm{g})$, the agonist and antagonist drugs were based on our pilot experimentation and from literature citations.

\subsection{Locomotor activity (open-field test)}

Mice were observed for locomotion in an open-field apparatus [21]. For the test, each animal was placed in the center of open-field arena, and persons who were unaware of treatments counted the locomotion frequency (the number of floor units the animal crossed with all the four paws) for a period of $4 \mathrm{~min}$, following $60 \mathrm{~min}$ of oral administration of OA $\left(30 \mathrm{mg} \mathrm{kg}^{-1}\right)$ or vehicle ( $2 \%$ Tween 80 in distilled water).

\subsection{Motor coordination (rota-rod test)}

The test was carried out according to the method described earlier [22]. The apparatus consisted of a horizontal bar 
with a diameter of $5 \mathrm{~cm}$, subdivided into four compartments (INSIGHT, RT-2002, Brazil). The mice were placed on the bar rotating at a speed of $4 \mathrm{rpm}$ and mice that were able to remain on the rod longer than $120 \mathrm{~s}$ were selected $24 \mathrm{~h}$ before the test. Mice ( $n=6$ per group) were orally treated with the vehicle or the $\mathrm{OA}\left(30 \mathrm{mg} \mathrm{kg}^{-1}\right)$ and $60 \mathrm{~min}$ later, each animal was tested on the rota-rod for its permanency(s) during a $2 \mathrm{~min}$ period.

\subsection{Statistical analysis}

Results were expressed as means \pm S.E.M. Statistical analysis of the results were evaluated using one-way analysis of variance (ANOVA) followed by the Dunnett's test for multiple comparisons. $p$-Values less than $0.05(p<0.05)$ were considered statistically significant.

\section{Results}

\subsection{Effect of $O A$ on capsaicin-induced hind paw nociception}

Intraplantar injection of capsaicin $(1.6 \mu \mathrm{g}, 20 \mu \mathrm{l})$ evoked nociceptive paw licking behavior in mice that appeared maximal during the first $5 \mathrm{~min}$. Vehicle $(20 \mu \mathrm{l}$ saline) injection induced only a minimal paw licking $(1.00 \pm 0.38 \mathrm{~s})$. Unlike capsaicin, OA failed to induce per se nociception following subplantar injection into the mouse hind paw (data not shown). The effects of systemic pretreatment with OA and ruthenium red (non-competitive capsaicin antagonist) on capsaicin-evoked nociception in mice are shown in Fig. 2. When compared to vehicle-treated controls, a significant decrease in the duration of paw licking was observed in mice pretreated with OA $(53 \%$, $68.5 \%$ and $36.6 \%$ ), respectively, for the doses of 10,30 and $100 \mathrm{mg} \mathrm{kg}^{-1}$. Ruthenium red $\left(3 \mathrm{mg} \mathrm{kg}^{-1}\right)$, the positive control used in the study also caused significant suppression of noci-

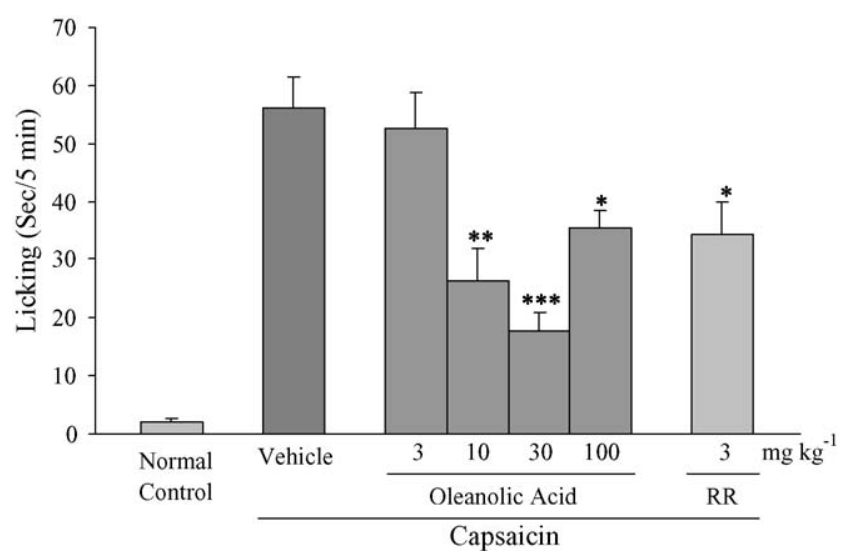

Fig. 2. Effects of oleanolic acid and ruthenium red on capsaicin-induced nociceptive behavior (paw licking) in mice. Oleanolic acid or vehicle ( $2 \%$ Tween 80 in distilled water, $10 \mathrm{ml} \mathrm{kg}^{-1}$ ) was administered orally and ruthenium red by intraperitoneal route, $1 \mathrm{~h}$ before intraplantar injection of capsaicin $(1.6 \mu \mathrm{g})$. Normal controls received normal saline $\left(10 \mathrm{ml} \mathrm{kg}^{-1}\right.$, p.o.) instead oleanolic acid. Each column represents mean \pm S.E.M. of $8-10$ animals per group. ${ }^{*} p<0.05$; ${ }^{* *} p<0.01{ }^{* * *} p<0.001$ vs. vehicle-treated group. ception (38.6\%). Since the inhibitory effect of $30 \mathrm{mg} \mathrm{kg}^{-1} \mathrm{OA}$ was maximal (68.5\% inhibition) on capsaicin-evoked nociception, subsequent experiments that attempted to elucidate the underlying mechanism were carried out at this dose. Fig. 3 shows the possible mechanisms involved in OA antinociception. The effect of OA was significantly blocked in animals pretreated with naloxone $\left(2 \mathrm{mg} \mathrm{kg}^{-1}\right.$, i.p. $)$, the opioid antagonist (Fig. 3A); L-arginine ( $600 \mathrm{mg} \mathrm{kg}^{-1}$, i.p.), the substrate for nitric oxide synthase (Fig. 3B); or glibenclamide $\left(2 \mathrm{mg} \mathrm{kg}^{-1}\right.$, i.p.), the $\mathrm{K}_{\mathrm{ATP}}$-channel blocker (Fig. $3 \mathrm{C}$ ), in a manner similar to respective positive controls: morphine (an opioid agonist), LNAME (the nitric oxide synthase inhibitor) and diazoxide (an opener of $\mathrm{K}_{\mathrm{ATP}}$-channels). L-NAME-alone significantly suppressed the capsaicin-evoked paw licking response while its combination with OA showed an augmented response (Fig. 3B). The $\alpha_{2}$-adrenoceptor antagonist, yohimbine $\left(2 \mathrm{mg} \mathrm{kg}^{-1}\right.$, i.p.) caused no significant blockade of antinociception produced by OA, but it, however, blocked the antinociception produced by clonidine $\left(0.1 \mathrm{mg} \mathrm{kg}^{-1}\right.$, i.p.), an $\alpha_{2}$-adrenoceptor agonist (Fig. 3D).

\subsection{Effects of OA in open-field and rota-rod tests}

$\mathrm{OA}$ administered orally at the dose of $30 \mathrm{mg} \mathrm{kg}^{-1}$ failed to produce any significant effect on locomotion frequency (control, $47.00 \pm 4.53 ; \mathrm{OA}, 44.67 \pm 2.11$ ) or on motor coordination (permanency time on rota-rod: control, $120 \mathrm{~s} ; \mathrm{OA}, 120 \mathrm{~s}$ ) in mice.

\section{Discussion}

In the present study, we have provided first evidence to show that $\mathrm{OA}$ administered orally inhibits capsaicin-evoked acute nociception in mice. Intraplantar capsaicin in mice is a widely accepted experimental model of nociceptive pain in which, the amount of time the animals spent licking the injected paw is taken as criterion while evaluating the antinociceptive effect of test substances $[23,24]$. In this model, OA produced a doserelated antinociception at doses of 10 and $30 \mathrm{mg} \mathrm{kg}^{-1}$, whereas, at a higher dose $\left(100 \mathrm{mg} \mathrm{kg}^{-1}\right)$ the response was much smaller, although attained statistical significance.

The antinociceptive effect of OA appears to involve endogenous opioids as it was blocked in mice pretreated with naloxone, a non-selective opioid antagonist. This supports the notion that compounds like OA might be useful as pain relievers. Past studies implicate the endogenous opioids as the mediators of the antinociceptive effects of $\mathrm{K}_{\mathrm{ATP}}^{+}$channel openers [25]. It is known that the intraplantar injections of capsaicin evoke increases in primary afferent activity in $\mathrm{C}$ - and $\mathrm{A} \delta$-nociceptors, TRPV1 receptor activation and cause accumulation of intracellular $\mathrm{Ca}^{2+}$, which is necessary for capsaicin-evoked transmitter release and neurogenic inflammation $[6,26] . \mathrm{K}_{\mathrm{ATP}}^{+}$channel openers such as diazoxide and morphine induce cell hyperpolarization, decrease the intracellular $\mathrm{Ca}^{2+}$ level and neurotransmitter release (calcitonin gene related peptide and substance P), that may account for antinociception $[27,25]$. To verify such a possibility, we examined the effect of glibenclamide, a blocker of $\mathrm{K}_{\mathrm{ATP}}^{+}$chan- 

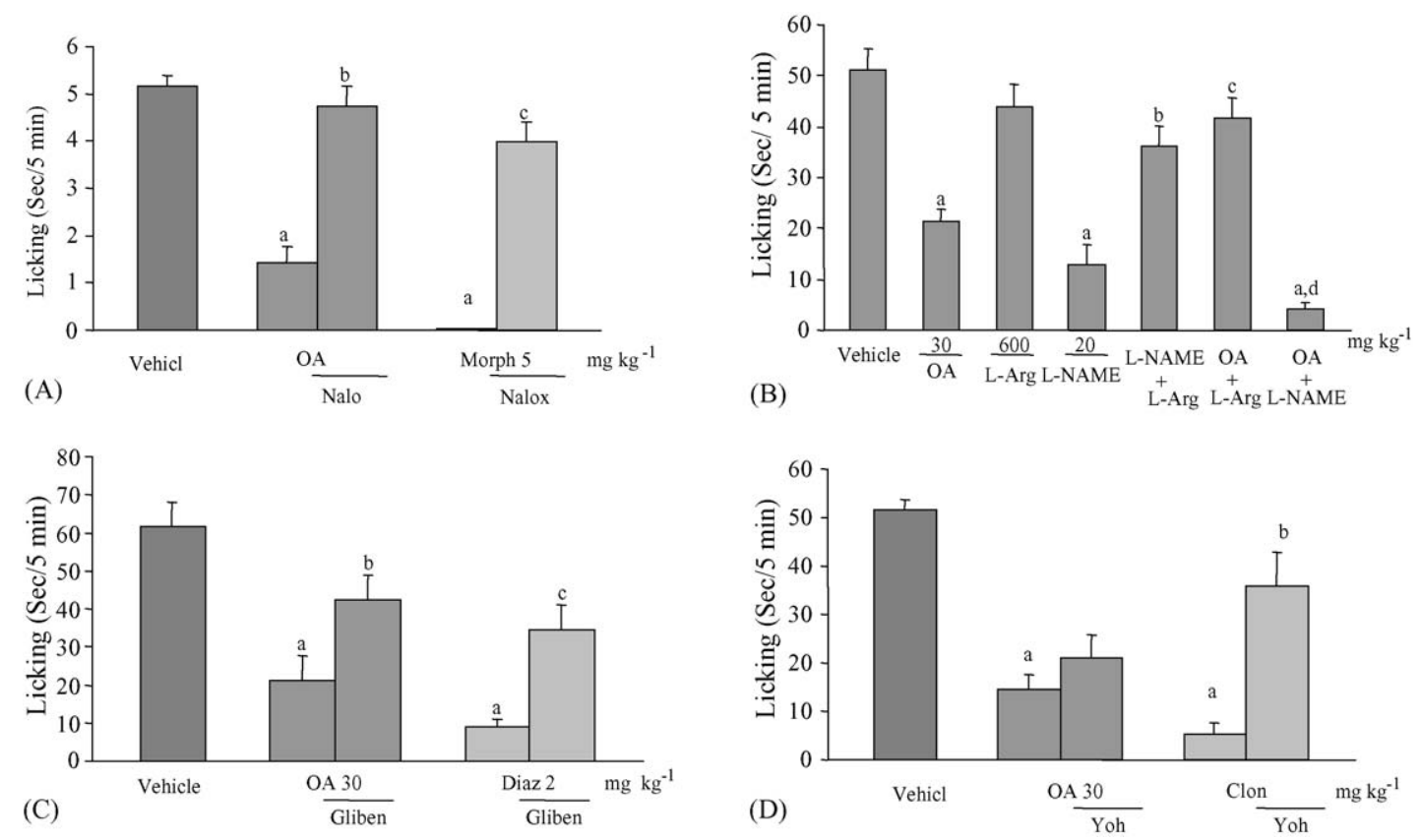

Fig. 3. Possible mechanisms involved in the antinociceptive effect of oleanolic acid on capsaicin-induced paw licking response in mice. (A) Involvement of opioid mechanism: naloxone (Nalox, $2 \mathrm{mg} \mathrm{kg}^{-1}$, i.p.) was administered $15 \mathrm{~min}$ before the oleanolic acid (OA, $30 \mathrm{mg} \mathrm{kg}^{-1}$, p.o.) or morphine (Morph, $5 \mathrm{mg} \mathrm{kg}$, , s.c.). Each column represents mean \pm S.E.M. of 8 animals per group. ${ }^{\mathrm{a}} p<0.001$ vs. vehicle; ${ }^{\mathrm{b}} p<0.001 \mathrm{vs.} \mathrm{OA} ;{ }^{\mathrm{c}} p<0.001$ vs. Morph. (B) Involvement of nitric oxide: L-arginine (L-Arg, $600 \mathrm{mg} \mathrm{kg}^{-1}$, i.p.) or L-NAME (20 mg kg${ }^{-1}$, i.p.)-alone or its combination with oleonolic acid (OA, $30 \mathrm{mg} \mathrm{kg}^{-1}$, p.o.) were administered $15 \mathrm{~min}$ before OA. Each column represents mean \pm S.E.M. of eight animals per group. ${ }^{\mathrm{a}} p<0.001$ vs. vehicle; ${ }^{\mathrm{b}} p<0.001$ vs. L-NAME; ${ }^{\mathrm{c}, \mathrm{d}} p<0.05$ vs. OA. (C) Involvement of ATPactivated potassium channels: animal groups were treated with diazoxide (diaz, $2 \mathrm{mg} \mathrm{kg}^{-1}$, i.p.) or glibenclamide (gliben, $2 \mathrm{mg} \mathrm{kg}^{-1}$, i.p)-alone or its combination with or without $\mathrm{OA}\left(30 \mathrm{mg} \mathrm{kg}^{-1}\right.$, p.o.). When combined, glibenclamide was administered $15 \mathrm{~min}$ before diazoxide or OA. Each column represents mean \pm S.E.M. of eight animals per group. ${ }^{\mathrm{a}} p<0.001 \mathrm{vs}$. vehicle; ${ }^{\mathrm{b}} p<0.05 \mathrm{vs.} \mathrm{OA} ;{ }^{\mathrm{c}} p<0.01 \mathrm{vs}$. diaz. (D) Role of $\alpha_{2}$-adrenoceptors: animal groups were treated with clonidine (clon, $0.1 \mathrm{mg} \mathrm{kg}^{-1}$, i.p.) or yohimbine (yoh, $2 \mathrm{mg} \mathrm{kg}^{-1}$, i.p.)-alone or its combination with or without $\mathrm{OA}\left(30 \mathrm{mg} \mathrm{kg}^{-1}\right.$, p.o.). When combined, yohimbine was administered $15 \mathrm{~min}$ before clonidine or OA. Each column represents mean \pm S.E.M. of eight animals per group. ${ }^{\mathrm{a}} p<0.001$ vs. vehicle; ${ }^{\mathrm{b}} p<0.001 \mathrm{vs}$. clon.

nels on OA antinociception. Interestingly, the data obtained show that the antinociception produced by OA is not only naloxone-sensitive but also sensitive to glibenclamide, suggesting the involvement of $\mathrm{K}_{\mathrm{ATP}}^{+}$channels. Earlier studies [28-30] point out that nitric oxide/cGMP activation and ATP-sensitive $\mathrm{K}^{+}$channel opening play a role in antinociception induced by morphine. In our study, the antinociception induced by OA is inhibited by opioid antagonist naloxone, by L-arginine, the substrate for nitric oxide synthase as well as by ATP-sensitive $\mathrm{K}^{+}$channel blocker glibenclamide, suggesting a possible role of endogenous opioids and the involvement of nitric oxidecGMP-ATP-sensitive $\mathrm{K}^{+}$channel pathway in its antinociceptive mechanism.

We also examined the possible involvement of $\alpha_{2}$ adrenoceptors in the antinociceptive effect of OA, using clonidine (agonist) or yohimbine (antagonist) pretreated mice. The results obtained indicate that both clonidine and oleanolic acid can suppress capsaicin-evoked nociception. However, yohimbine antagonized only the antinociceptive effect of clonidine but not that of OA, suggesting that $\alpha_{2}$-adrenoceptors play no significant role. The results of the present study further suggest the involvement of L-arginine-nitric oxide (NO) pathway in the antinociception caused by OA. Pretreatment of mice with the substrate of nitric oxide synthase, L-arginine, at a dose that produced no significant effect on intraplantar capsaicin-evoked pain, significantly reversed the antinociception produced by both
OA and L-NAME, a known nitric oxide inhibitor. It is interesting to note from the present data that L-NAME alone attenuated the capsaicin nociception indicating the active role of $\mathrm{NO}$ in capsaicin nociception. Its combination with OA, however, showed apparently a potentiated/additive response (Fig. 3B), which needs further analysis through an isobolographic study.

$\mathrm{OA}$ is a natural triterpenoid ubiquitous in plant kingdom and is a component of many medicinal herbs. Although relatively safe and non-toxic [11], the selection of the appropriate dose is critical. At low-doses, OA offers gastroprotection, hepatoprotection and functions as chemopreventive, while in high-dose could produce cholestasis and hepatotoxicity [16,11]. In the present study OA demonstrated potential antinociceptive effect in fairly low-doses and at the dose that produced maximal inhibition of capsaicin-nociception $\left(30 \mathrm{mg} \mathrm{kg}^{-1}\right)$ neither impaired locomotion nor the motor coordination of mice in the respective tests of open-field and rota-rod, which implies that OA is an ideal molecule for rational drug development to alleviate neuropathic or inflammatory pain. In conclusion, the present study provides the first evidence for the antinociceptive effect of OA in capsaicin model of nociception and this observation was complementary to our previous experiments that reveal its efficacy in suppressing visceral nociception induced by mustard oil. The data obtained further suggest that its antinociceptive action is at least, in part, related to endogenous opioid receptor stimulation, nitric oxide production and activation of ATP-gated $\mathrm{K}^{+}$channels. 


\section{Acknowledgments}

The authors gratefully acknowledge the financial support from CNPq (proc. nos. 472717/2003-0 and 504920/2003-0), Brazil, and the technical assistance of Miss. Aline Bastos Ferreira.

\section{References}

[1] Buck SH, Burks TF. The neuropharmacology of capsaicin: review of some recent observations. Pharmacol Rev 1986;38:179-226.

[2] Caterina MJ, Leffler A, Malmberg AB, Martin WJ, Trafton J, PetersenZeitz KR, et al. Impaired nociception and pain sensation in mice lacking the capsaicin receptor. Science 2000;288:306-13.

[3] Szolcsányi J. Forty years in capsaicin research for sensory pharmacology and physiology. Neuropeptides 2004;38:377-84.

[4] Bolcskei K, Helyes Z, Szabó Á, Sándor K, Elekes K, Németh J, et al. Investigation of the role of TRPV1 receptors in acute and chronic nociceptive processes using gene-deficient mice. Pain 2005;117:365-76.

[5] McNamara FN, Randall A, Gunthorpe MJ. Effects of piperine, the pungent component of black pepper, at the human vanilloid receptor (TRPV1). Brit J Pharacol 2005;144:781-90.

[6] Szolcsányi J. Capsaicin-sensitive sensory nerve terminals with local and systemic efferent functions: facts and scopes of an unorthodox neuroregulatory mechanism. Prog Brain Res 1999;113:343-59.

[7] Walker KM, Urbn L, Medhurst J, Patel S, Panesr M, Fox AJ, et al. The VR1 antagonist capsazepine reverses mechanical hyperalgesia in models of inflammatory and neuropathic pain. J Pharmacol Exp Ther 2003;304:56-62.

[8] Lopez-Rodriguez ML, Viso A, Ortega-Gutierrez S. VR1 receptor modulators as potential drugs for neuropathic pain. Mini Rev Med Chem 2003;3:729-48.

[9] El Kouhen R, Surowy CS, Bianchi BR, Neelands TR, McDonald HA, Niforatos W, et al. A-425619 [1-isoquinolin-5-yl-3-(4-trifluoromethylbenzyl)-urea], a novel and selective transient receptor potential type V1 receptor antagonist, blocks channel activation by vanilloids, heat, and acid. J Pharmacol Exp Ther 2005;314:400-9.

[10] Sterner O, Szallasi A. Novel natural vanilloid receptor agonists: new therapeutic targets for drug development. Trends Pharmacol Sci 1999;20:459-65.

[11] Liu J. Pharmacology of oleanolic acid and ursolic acid. J Ethnopharmacol 1995;49:57-68.

[12] Choi J, Jung HJ, Lee KL, Park HJ. Antinociceptive and antiinflammatory effects of the saponin and sapogenins obtained from the stem of Akebia quinata. J Med Food 2005;8:78-85.

[13] Lukaczer D, Darland G, Tripp M, Liska D, Lerman RH, Schiltz B, et al. A pilot trial evaluating META050, a proprietory combination of reduced iso-alpha acids, rosemary extract and oleanolic acid in patients with arthritis and fibromyalgia. Phytother Res 2005;19:864-9.
[14] Singh GB, Singh S, Bani S, Gupta BD. Anti-inflammatory activity of oleanolic acid in rats and mice. J Pharm Pharmacol 1992;44:456-8.

[15] Rodríguez JA, Astudillo L, Schmeda-Hirchmann G. Oleanolic acid promotes healing of acetic acid-induced chronic gastric ulceration in rats. Pharmacol Res 2003;48:291-4.

[16] Ovesná Z, Vachalkova A, Horvathova K, Tothova D. Pentacyclic triterpenic acids: new chemoprotective compounds. Minirev Neoplasma 2004;51:327-33.

[17] Maia JL, Lima-Junior RC, David JP, David JM, Santos Fa, Rao VS Oleanolic acid, a pentacyclic triterpene attenuates the mustard oilinduced colonic nociception in mice. Biol Pharm Bull 2006;29:82-5.

[18] Zimmermann M. Ethical guidelines for investigations of experimental pain in conscious animals. Pain 1983;16:109-10.

[19] David JP, Da Silva EF, De Moura DL, Guedes MLS, Assunção RJ, David JM. Lignans and triterpenes from cytotoxic extract of Eriope blanchetii. Quim Nova 2001;24:730-3.

[20] Santos ARS, Calixto JB. Further evidence for the involvement of tachykinin receptor subtypes in formalin and capsaicin models of pain in mice. Neuropeptides 1997;37:381-9.

[21] Capaz FR, Vanconcellos LE, De Moraes S, Neto JP. The open field: a simple method to show ethanol withdrawal symptoms. Archiv Int Pharmacodyn Ther 1981;251:228-36.

[22] Rosland JH, Hunskaar S, Hole K. Diazepam attenuates morphine antinociception test-dependently in mice. Pharmacol Toxicol 1990;66:382-6.

[23] Kobayashi Y. The nociceptive and antinociceptive effects of evodiamine from fruits of Evodia rutaecarpa in mice. Planta Med 2003;69:425-8.

[24] Sakurada T, Matsumura T, Moriyama T, Sakurada C, Ueno S, Sakurada S. Differential effects of intraplantar capsazepine and ruthenium red on capsaicin-induced desensitization in mice. Pharmacol Biochem Behav 2003;75:115-21.

[25] Lohmann AB, Welch SP. ATP-gated $\mathrm{K}^{+}$channel openers enhance opioid nociception: indirect evidence for the release of endogenous opioid peptides. Eur J Pharmacol 1999;385:119-27.

[26] Sakurada T, Matsumura T, Moriyama T, Sakurada C, Ueno S, Sakurada S. Differential effects of intraplantar capsazepine and ruthenium red on capsaicin-induced desensitization in mice. Pharmacol Biochem Behav 2003;75:115-21

[27] Ocana M, Cendán CM, Cobos EJ, Entrena JM, Baeyens JM. Potassium channels and pain: present realities and future opportunities. Eur J Pharmacol 2004;500:203-19.

[28] Duarte IDG, Lorenzetti BB, Ferreira SH. Peripheral analgesia and activation of the nitric oxide-cyclic GMP pathway. Eur J Pharmacol 1990;186:289-91.

[29] Duarte IDG, Ferreira SH. The molecular mechanism of central analesia induced by morphine or carbachol and the L-arginine-nitric oxide-cGMP pathway. Eur J Pharmacol 1992;221:271-4.

[30] Rodrigues ARA, Duarte IDG. The peripheral antinociceptive effect induced by morphine is associated with ATP-sensitive $\mathrm{K}^{+}$channels. Brit J Pharmacol 2000;129:110-4. 